Board of Governors of the Federal Reserve System

International Finance Discussion Papers

Number 1096

December 2013

\title{
Do Small Businesses Still Prefer Community Banks?
}

Allen N. Berger, William Goulding, and Tara Rice

NOTE: International Finance Discussion Papers are preliminary materials circulated to stimulate discussion and critical comment. References to International Finance Discussion Papers (other than an acknowledgment that the writer has had access to unpublished material) should be cleared with the author or authors. Recent IFDPs are available on the Web at www.federalreserve.gov/pubs/ifdp/. This paper can be downloaded without charge from Social Science Research Network electronic library at http://www.ssrn.com. 


\title{
Do small businesses still prefer community banks?
}

\author{
Allen N. Berger \\ University of South Carolina \\ Wharton Financial Institutions Center \\ CentER - Tilburg University \\ aberger@moore.sc.edu \\ William Goulding \\ Massachusetts Institute of Technology \\ Sloan School of Management \\ bill.goulding@sloan.mit.edu \\ Tara Rice \\ Board of Governors of the Federal Reserve System \\ tara.rice@,frb.gov
}

December 2013

\begin{abstract}
We formulate and test hypotheses about the role of bank type - small versus large, single-market versus multimarket, and local versus nonlocal banks - in banking relationships. The conventional paradigm suggests that "community banks" - small, single-market, local institutions - are better able to form strong relationships with informationally opaque small businesses, while "megabanks" - large, multimarket, nonlocal institutions tend to serve more transparent firms. Using the 2003 Survey of Small Business Finance (SSBF), we conduct two sets of tests. First, we test for the type of bank serving as the "main" relationship bank for small businesses with different firm and owner characteristics. Second, we test for the strength of these main relationships by examining the probability of multiple relationships and relationship length as functions of main bank type and financial fragility, as well as firm and owner characteristics. The results are often not consistent with the conventional paradigm, perhaps because of changes in lending technologies and deregulation of the banking industry.
\end{abstract}

JEL Classification Numbers: G21, G28, G34

Keywords: Banks, Relationships, Small business, Government policy.

The authors thank Rebel Cole, Bob DeYoung, Leora Klapper, Sole Martinez Peria, Paula Tkac, and participants in the Federal Reserve Bank of Atlanta conference on Small Business, Entrepreneurship and Economic Recovery and the CEPR/ECB/Kelley School of Business/ Review of Finance Conference on Small Business Financing for helpful comments and suggestions and Michael Levere and Michael Carlson for valuable research assistance.

The views expressed in this paper are those of the authors only, and should not be interpreted as reflecting the views of the Federal Reserve Board of Governors, its staff, or the Federal Reserve System. 


\section{Introduction}

Banks are a critical source of funding for small firms, providing about $60 \%$ of debt financing to small businesses (Survey of Small Business Finance, 2003). Small business lending is also important to banks: Both small and large banks extend significant amounts of small business loans. Despite the importance of the banks to small businesses (and vice versa), surprisingly little is known about the characteristics of banks and small businesses and their relationships with each other. In this paper, we examine bank types and their relationships with small businesses.

Banks often extract proprietary information from strong relationships and use this information to set future contract terms and make future credit underwriting decisions. The extant research suggests that small businesses benefit from relationships in terms of credit availability, credit terms, and firm performance. Yet strong relationships, particularly when they are exclusive, may also involve costs associated with a hold up problem - extraction of rents from a captured firm - or with the potential for premature withdrawal of services if the bank becomes financially distressed or fails. Exclusive relationships with certain types of banks may also be inherently more fragile if these types are more likely to sever small business relationships or withdraw credit than other types. Firms often bear the duplicative costs of multiple banking relationships to mitigate these problems.

Arguments in the literature suggest that small banks are better able to form strong relationships with informationally opaque small businesses, while large banks tend to serve more transparent firms because dealing with opaque firms requires the use of soft information and such information is difficult to quantify and transmit through the communication channels and layers of management of large organizations (e.g., Berger and Udell 2002, Stein 2002). Much of the early empirical literature provides support for this conventional wisdom (e.g., Haynes, Ou, and Berney 1999, Cole, Goldberg, and White 2004, Scott 2004, Berger, Miller, Petersen, Rajan, and Stein 2005). ${ }^{1}$ By extension, the arguments about the difficulties of large banks in dealing with the soft information of opaque small firms may apply to multimarket and nonlocal banks as well. Thus, it is expected under the conventional wisdom in the literature that opaque small businesses would be best served by small, single-market, local banks, while large, multimarket, nonlocal institutions would tend to serve more transparent firms.

\footnotetext{
${ }^{1}$ Also consistent with the conventional wisdom, Gilje (2012) finds that a higher local market share for small banks increases the number of establishments in industries most dependent on external finance when local deposits increase.
} 
If this conventional paradigm is correct, banking industry consolidation may have significant consequences for the effectiveness of banking relationships with small businesses. Small banks, single-market banks, and local banks may more often function as "community banks" that use soft information gathered from relationships with the firm, its owner, and local community, while large banks, multimarket banks, nonlocal banks may act more as "megabanks" with weaker community ties that base their relationships primarily on hard information about the firm. Bank consolidation may also affect the competitiveness of local banking markets, which may alter the strength of relationships and the benefits and costs of these relationships to small businesses.

The large banks, multimarket banks, and nonlocal banks created by consolidation may be disadvantaged in relationships based on soft information and may be more likely to sever relationships or withdraw credit than the small, single-market, and local institutions they replace. During the financial crisis of 2007-2009, small businesses saw their bank borrowing contract precipitously. Numerous reports cite small business owners' difficulty in obtaining access to credit over the crisis period, particularly from large banks. ${ }^{2}$

Recently, however, a number of articles challenge the conventional paradigm. Berger and Udell (2006) suggest that large banks may be able to serve opaque firms well using hard-information technologies, such as credit scoring and lending against fixed asset collateral (real estate, motor vehicles, or equipment) with values that are relatively easy to assess. A number of empirical articles suggest that very large banks are able to increase their lending to opaque small businesses using credit scoring technology (e.g., Frame, Srinivasan, and Woosley 2001, Frame, Padhi, and Woosley 2004, Berger, Frame, and Miller 2005) and two studies find that small business credit scoring is responsible for an increase in lending distance over time (Frame, Padhi, and Woosley 2004, DeYoung, Frame, Glennon, and Nigro 2011). Empirical results in Berger, Rosen, and Udell (2007) do not suggest a significant net advantage or disadvantage for large banks in small business lending overall, or in lending to informationally opaque small businesses in particular. Rather, the relative convenience of large banks, represented by their local market share of deposits, appears to be most important in determining lender size. Berger and Black (2011) find that large banks tend to lend to both the smallest and the largest small businesses, with small banks specializing in lending to medium-sized small firms. Canales and Nanda (2011) find that large

\footnotetext{
${ }^{2}$ Testimony of Governor Elizabeth A. Duke before the Committee on Financial Services and Committee on Small Business, U.S. House of Representatives, Washington, D.C., February 26, 2010 (http://www.federalreserve.gov/newsevents/testimony/duke20100226a.htm) and National Federation of Independent Businesses, Small Credit in a Deep Recession, February 2010.
} 
banks with decentralized decision making lend more to small businesses and respond more to local market competition, consistent with behavior typically associated with small banks that make relationship loans. Berger and Black (2011) and Berger, Cowan, and Frame (2011) find that small banks use hard-information technologies, fixed asset lending and credit scoring, respectively, in addition to relationship lending. de la Torre, Martinez Peria, and Schmukler (2010) find that both large and small banks cater to small firms. Finally, one paper finds that the conventional wisdom held for recent startups in the mid-2000s - in that a higher local market share of branches owned by small banks resulted in more bank credit to startups - but did not hold for these firms in the recent financial crisis (Berger, Cerqueiro, and Penas 2013). ${ }^{3}$

Despite these important issues and the recent controversy over the conventional paradigm, surprisingly little empirical effort has been devoted to investigating the type of bank that tends to serve as the main relationship bank with opaque small businesses and which types of main banks tend to be associated with stronger relationships with these firms. For our purposes, we define a firm's "main" relationship bank as the "primary" financial institution identified by the firm. The objective of this paper is to expand the literature along these lines. We test hypotheses about the role of bank type - small versus large, single-market versus multimarket, and local versus nonlocal banks - in banking relationships. In effect, we expand the conventional wisdom about the roles of small banks to single-market and local banks and the roles of large banks to multimarket and nonlocal banks, and test the conventional wisdom. Specifically, we test whether "megabanks" (large, multimarket, nonlocal) less often serve as the main relationship bank than "community banks" (small, single-market, local) for opaque small businesses, and whether the main bank relationships of megabanks are weaker than those of "community banks." Our application matches U.S. small business data from the 2003 Survey of Small Business Finance (SSBF) to the Consolidated Reports of Condition and Income for U.S. Banks (Call Report) on the banks that provide them with credit and other services, and the Summary of Deposits data on the competitive conditions in their local banking markets.

We conduct two sets of tests. First, we test for the type of bank serving as the main relationship bank identified by small businesses. Prior analyses of U.S. data typically do not focus on main banking relationships - they usually examine the relationship for a single loan at a time, and often do not match the loan to the bank

\footnotetext{
${ }^{3}$ In a related paper, Durguner (2012) shows that the importance of small business lending relationships in determining loan contract terms has diminished over time. Consistent with this, van Ewijk and Arnold (2013) find that U.S. banks have shifted from relationship-oriented models towards transactions-oriented models over time.
} 
type. ${ }^{4}$ We include exogenous variables measuring firm characteristics (e.g., firm size and age, ownership type, and industry), principal owner characteristics (e.g., if owner is also manager, has majority share, has had personal financial problems), and local banking market competition (e.g., concentration, market shares of large and multimarket banks, branches per capita, state banking restrictions). We test the hypothesis from the conventional paradigm that relatively opaque firms - measured by firm size, age, owner involvement, and several other characteristics - tend to have their main banking relationship with small, single-market, and local banks. Under the paradigm, these banks are expected to have advantages in soft-information-based relationships relative to large, multimarket, and nonlocal banks, respectively. More transparent small businesses that rely more on hard-information-based relationships are expected to have their main relationships more frequently at large, multimarket, and nonlocal banks.

Second, we test for the strength of these main relationships by examining the probability of an exclusive relationship versus multiple banking relationships and the length of a relationship as functions of the main bank type and its financial fragility, as well as firm, owner, and market characteristics. Under the conventional paradigm, relatively small, young firms with more "important" principal owners (i.e., owner-managers with large stakes in their firms) and otherwise opaque small businesses tend to have stronger, more exclusive relationships to deal with their soft information problems, whereas larger, more mature, firms with less “important" principal owners (i.e., non-managers with small stakes) may more often engage in multiple banking to reduce hold up and financial distress concerns. Larger firms may also more often have multiple banks because a single bank cannot provide all the financial services they need. In addition, under the conventional paradigm, it is expected that - even after conditioning on firm and owner characteristics - relationships with small, single-market, and local banks or "community banks" are likely to be stronger and more exclusive than those with large, multimarket, and nonlocal banks or "megabanks" because the former relationships are more likely to be based significantly on soft information. In addition, firms may avoid single relationships with "megabanks" because of the fragility of these relationships. These banks may have weaker ties to the local community and may be more likely to sever small business relationships or withdraw soft-information-based credit than "community banks."

\footnotetext{
${ }^{4}$ Studies of German hausbanks are examples in which main banking relationships are examined. Hausbanks are found to provide liquidity insurance to their customers (e.g., Elsas and Krahnen 1998). Hausbanks are also found to have better access to information, more influence on borrower management, and to provide relatively high shares of borrower debt (Elsas 2005).
} 
By way of preview, our empirical results are often not consistent with the predictions of the conventional paradigm. In the first test, we find that opaque small businesses are not more likely to have a community bank as their main bank. In the second test, we find mixed evidence on whether opaque small businesses have stronger relationships with their main banks, but the evidence is clearer that strength does not depend on the type of bank.

We conjecture that the conventional paradigm may not hold because of two important changes in the banking industry over time: 1) changes in lending technology, specifically the introduction of credit scoring in small business lending, and 2) changes in bank regulation (such as the Riegle Neal Interstate Banking and Branching Efficiency Act of 1994 (IBBEA)) that allows large, multimarket, and nonlocal banks to integrate offices across state lines. As discussed below, we also try using the 1993 SSBF, because this survey occurred before the widespread use of small business credit scoring and IBBEA.

The remainder of the paper is organized as follows. Section 2 briefly reviews the relevant literature on banking relationship strength and associated research and policy issues. Section 3 discusses the data set and provides summary statistics. Section 4 presents the empirical methodology. Section 5 presents the empirical results, and Section 6 concludes.

\section{Brief review of the relationship strength literature and associated issues}

\section{Relationship strength}

Relationship strength is generally measured by the length or breadth of the relationship, or whether the bank is the exclusive provider of loans and other services. Strong relationships may often be needed to extract proprietary soft information and to lend to small firms without sufficient hard information on which to base credit decisions. Firms of all types may also benefit from strong banking relationships in which the bank is able to "reuse" hard and soft information garnered over the course of the relationship from loans, deposits, or other services to set future contract terms or make future credit underwriting decisions. As will become clear, the literature suggests that different types of banks - small versus large, single-market versus multimarket, and local versus nonlocal - may have different abilities to maintain strong relationships with small businesses.

\section{Benefits from strong relationships}

Most empirical studies find benefits to borrowers from strong relationships. The research often finds that stronger relationships are associated with better credit availability, as measured by a higher loan application 
acceptance rate, less dependence on expensive trade credit, or more loans without collateral requirements (e.g., Petersen and Rajan 1994, 1995, Berger and Udell 1995, Cole 1998, Elsas and Krahnen 1998, Harhoff and Korting 1998, Machauer and Weber 2000). Studies of U.S. small businesses typically also find lower loan interest rates when relationships are stronger (e.g., Petersen and Rajan 1994, Berger and Udell 1995), although European studies often yield no significant effects of relationship strength on rates (e.g., Elsas and Krahnen 1998, Harhoff and Korting 1998, Machauer and Weber 2000, Degryse and Cayseele 2000). Some recent studies also discover favorable effects of strong relationships on firm performance. Specifically, one study of publicly traded U.S. companies finds that strong relationships increase the likelihood of success of moderately financially distressed firms (Rosenfeld 2011), another study finds that relationships aid in resolution of Chapter 11 bankruptcy proceedings (Dahiya, John, Puri, and Ramirez 2003), and a study of Italian manufacturers yields a positive association between relationship strength and innovation by borrowing firms (Herrera and Minetti 2007). ${ }^{5}$

\section{Costs to strong relationships that may result in multiple banking}

Strong relationships - particularly when they are exclusive - may also involve costs. The private information generated by an exclusive banking relationship may give the bank market power over the firm, yielding a hold up problem and extraction of rents from the firm (e.g., Sharpe 1990, Rajan 1992). Firms may bear additional costs to engage in multiple relationships to mitigate the rent extraction (e.g., Von Thadden 1992, Boot 2000, Farinha and Santos 2002, Elsas, Heinemann, and Tyrell 2004). ${ }^{6}$

Firms may also bear the duplicative costs of multiple banking instead of a single strong banking relationship to protect themselves from premature withdrawal of services if their main bank becomes financially distressed or fails. Thus, firms may be more likely to have multiple banking relationships when their main bank is financially fragile and likely to become distressed or fail. The empirical literature on this topic is mixed, with studies in some cases finding positive, negative, and/or no consistent effect of bank fragility on the probability of multiple banking (e.g., Detragiache, Garella, and Guiso 2000, Ongena and Smith 2000, Berger, Klapper, and Udell 2001, Berger, Klapper, Martinez Peria, and Zaidi 2008). ${ }^{7}$

\footnotetext{
${ }^{5}$ One recent study also documents some of the benefits to lenders from relationships in terms of increased future profitable lending opportunities (Bharath, Dahiya, Saunders, and Srinivasan 2007).

${ }^{6}$ The extraction of rents may also make it profitable for banks to lend to some additional firms with marginal credit quality, improving the credit availability of these marginal firms (e.g., Petersen and Rajan 1995).

${ }^{7}$ A possible issue with these studies is that they typically do not measure the fragility of the main bank, but rather the fragility of one lending bank or all of the firm's banks. We argue that the fragility of the main bank is the most logical choice, based on the assumption that the main bank is determined first.
} 
The concept of relationship fragility may also be extended to apply to bank type if some types of banks are more likely to sever relationships or withdraw critical services, independent of the bank's financial condition. In this regard, there is no literature on small versus large, single-market versus multimarket, or local versus nonlocal banks on relationship severance. However, there are related studies on the effects of domestic versus foreign banks - an extreme form of local versus nonlocal banks. One study of Indian banking suggests that foreign banks have weaker ties to the country and may be more likely to sever relationships with local firms than state-owned banks with mandates to serve local firms (Berger, Klapper, Martinez Peria, and Zaidi 2008). A related literature finds that foreign banks generally reduced lending more than domestic banks during crisis periods (Klein, Peek, and Rosengren, 2002, Claessens and Van Horen, 2011, de Haas and Lelyveld, 2011, Popov and Udell, 2012, Ongena, Peydró, and van Horen, 2012). In the present context, it may be analogously expected that large, multimarket, and nonlocal banks have weaker ties to the local community and may be more likely to sever small business relationships or cut off credit than small, single-market, and local institutions, respectively.

Finally, firms may more often bear the duplicative costs of multiple banking when one bank cannot provide all of their financial service needs. This is likely to occur only for the largest of the small businesses studied here, which may be geographically dispersed, requiring services in more markets than are served by the firm's main bank. Multiple banks may similarly be needed if the firm requires international services or specialized investment products not provided by the firm's main bank or it operates over a geographic region not fully served by one bank. Empirical research typically finds that larger firms are associated with multiple banking (e.g., Houston and James 1996, Machauer and Weber 2000, Ongena and Smith 2000, Berger, Klapper, and Udell 2001, Berger, Miller, Petersen, Rajan, and Stein 2005, Berger, Klapper, Martinez Peria, and Zaidi 2008)..$^{8,9}$

\section{Strong relationships and bank consolidation issues}

Some research and policy issues concern the effects of bank consolidation on relationships. Much of the relationship lending literature focuses on the effects of bank size, hypothesizing that larger banks are

\footnotetext{
${ }^{8}$ Other motives for multiple banking relationships are discussed in Berger, Klapper, Martinez Peria, and Zaidi (2008).

${ }^{9}$ These incentives for multiple banking also apply to diversification across relationship types. That is, firms may be more likely to diversify to mitigate a hold up problem by a type of bank, to protect against premature withdrawal of services by a type of bank, and/or fulfill different service needs provided by different types of banks. We are aware of only one prior study of bank type diversification, and it does find evidence consistent with these incentives (Berger, Klapper, Martinez Peria, and Zaidi 2008).
} 
disadvantaged in relationships to small firms based on soft information due to difficulties in processing and transmitting soft information through the communication channels of large organizations (e.g., Stein 2002), agency problems within large organizations with more layers of management because the loan officer is the main repository of soft information (e.g., Berger and Udell 2002), and/or organizational diseconomies of dealing with using hard-information-based technologies for some firms along with soft-information-based technologies for other firms (e.g., Williamson 1988). Large banks may have a comparative advantage in relationships with larger firms due to economies of scale in processing and transmitting hard information.

Some empirical research is consistent with these expectations that large banks are less likely than small banks to lend to or have strong relationships with small, young firms with little hard information available and conversely for relationships with large, mature firms with more hard information available (e.g., Haynes, Ou, and Berney 1999, Cole, Goldberg, and White 2004, Scott 2004, Berger, Miller, Petersen, Rajan, and Stein 2005). Thus, bank consolidation may have unfavorable implications for firms relying on relationships that make primary use of soft information and conversely for firms relying on relationships based primarily on hard information. ${ }^{10}$

Presumably, arguments similar to those based on bank size apply to the geography of banks - singlemarket and local banks are more likely to have a comparative advantage in relationships based on soft information, and multimarket and nonlocal banks are more likely to have a comparative advantage in hardinformation-based relationships. Some of the recent industrial organization research on banking focuses on differences in competitive behavior and efficiencies of multimarket versus single-market banks and their effects on small businesses and consumers, but does not examine the role of relationships (e.g., Hannan and Prager 2006, Berger, Dick, Goldberg, and White 2007, Cohen and Mazzeo 2007, Berger and Ostromogolsky 2009). Similarly, there has been research showing that lending distances have increased over time, with more small businesses borrowing from nonlocal lenders (e.g., Petersen and Rajan 2002, Hannan 2003, Brevoort and Hannan 2006). This literature also usually does not focus on relationships, despite the likely role of soft information in local relationships and hard information in nonlocal relationships. Thus, the consolidation of the banking industry may be expected to shift resources from small, single-market, and local banks to large, multimarket,

\footnotetext{
${ }^{10}$ However, some research finds that market reactions may offset some of these consequences. Some studies of bank mergers and acquisitions find that small business lending appears to decline at consolidating institutions, but may be offset by increased lending supplies by other banks in the market or through increased market entry of newly chartered banks (e.g., Berger, Saunders, Scalise, and Udell 1998, Avery and Samolyk 2004, Berger, Bonime, Goldberg, and White 2004).
} 
nonlocal institutions, with potentially significant consequences for banking relationships and their benefits to small businesses.

Consolidation may also affect the competitiveness of local banking markets. Mergers and acquisitions (M\&As) within markets likely reduces competitiveness and M\&As across markets likely increase competitiveness. Relationship strength and its consequences may be greater when banking markets are less competitive, because firms have fewer potential alternatives in the future event that their main bank tightens contract terms dramatically. Empirical studies of the effects of concentration and other restrictions on competitiveness on measures of credit availability, activity, and general economic performance find both favorable effects (e.g., Petersen and Rajan 1995, Cetorelli and Gambera 2001, Bonaccorsi di Patti and Dell'Ariccia 2004, Cetorelli 2004) and unfavorable effects (e.g., Black and Strahan 2002, Berger, Hasan, and Klapper 2004, Karceski, Ongena, and Smith 2005, Cetorelli and Strahan 2006).

\section{Data and Summary Statistics}

We combine data from the SSBF with the Call Reports. The SSBF is a survey by the Federal Reserve of the financial condition of firms with fewer than 500 full-time-equivalent employees. The survey was first conducted in 1987 and repeated in 1993, 1998, and 2003. It contains details on small businesses' income, expenses, assets, liabilities, and characteristics of the firm, firm owners, and the small businesses' financial relationships with financial service suppliers for a broad set of products and services. The sample is randomly drawn but stratified to ensure geographical representation across all regions of the United States. The SSBF also oversamples relatively large firms (conditional on having fewer than 500 workers). Given the above data, we can measure assets, liabilities, profits, firm age, and the length of time firms have established relationships with banks and other lenders. We also know the location of firms, so we can control for local market conditions. The SSBF data also collects information on the financial service suppliers to the surveyed firms, such as loans, deposits, and other financial services used by each firm.

Petersen and Rajan (1994) and Berger and Udell (1995) are among the first to use the data from the 1987 survey. These papers both find that banking relationships expand credit availability for small firms. Other authors also use later waves of these data to study whether bank size affects credit allocation decisions (e.g., Cole 1998, Jayaratne and Wolken 1999, Cole, Goldberg, and White, 2004, Berger, Miller, Petersen, Rajan, and 
Stein 2005, Berger and Black 2011). Our paper is the first to use these data to test role of bank type - small versus large, single-market versus multimarket, and local versus nonlocal banks - in banking relationships.

The SSBF data contain information on up to 20 financial services firms with which a small business may have a relationship. We match the small businesses' banks with the Call Reports, which contain financial statement and structure data on all U.S. commercial banks.

We exclude a number of firms from the sample. Of the 4240 firms in the SSBF, 3350 are in metropolitan markets. We restrict our study to metropolitan markets because lending practices vary greatly between metropolitan and rural markets, and the sample of rural banks would be too small to analyze. DeYoung, Glennon, Nigro, and Spong (2012) find fundamental differences between small rural and metropolitan business borrowers and conclude that divergent lending practices made necessary by these differences may result in a greater number of small rural commercial banks than would be expected. Moreover, because soft information may be more difficult to convey across rural markets to metropolitan markets, rather than within rural or metropolitan markets, small rural borrowers will be less able to borrow from nonlocal lenders.

Of the 3350 metropolitan firms, 2846 identified a commercial bank as their primary institution. We drop 504 firms from the sample that either did not have a commercial bank as a primary institution or provided an incomplete response to the question, leaving the identity of the main institution uncertain. ${ }^{11}$

Table 1 Panel A reports the definitions of the variables used in the analyses taken from the $2003 \mathrm{SSBF}$ matched with the Call Reports. The firm characteristics include measures of firm size, minority ownership, age, risk, and industry, and if the firm has a bank loan. For firm size, we specify dummies for small, medium, and large firms, with total assets $\leq \$ 100,000, \$ 100,000$ - \$1 million, and over $\$ 1$ million, respectively, with small firms excluded as the base case in the regressions. Note that these are relative sizes within the broader category of small businesses that are in the SSBF, and do not include the largest firms in the nation. Prior research finds significant differences across these three size classes in the comparative advantages of large and small banks in using different lending technologies (Berger and Black 2011). For firm age, we simply specify the natural log of age. Age is a measure of opacity and has been found to affect the likelihood of borrowing from large banks

\footnotetext{
${ }^{11}$ As is noted in the table descriptions, specifications that use data from the Bank Call Reports and the Summary of Deposits have 2614 observations after merging with these data.
} 
in prior research (e.g., Berger, Miller, Petersen, Rajan, and Stein 2005, Berger, Rosen, and Udell 2007). For firm risk, we include a measure of credit score, leverage, and a dummy that equals 1 if the business has been delinquent in the past three years. We also control for industry type with dummies for construction, retailing, services, and manufacturing (not shown in tables for brevity).

The owner characteristics include measures of organizational form and the involvement or "importance" of the principal owner in the life of the firm. Organizational form includes dummies for whether the firm is a corporation, partnership, or proprietorship, as these forms offer the firm different protections of assets in the event that they do not repay their bank credit and may also reflect the need for soft information in their banking relationships. We include variables measuring whether the principal owner of the firm is also the manager, and whether the firm is owned exclusively by a single family.. When the owner is also the manager, has a large stake in the firm, and has personal financial problems, it is more likely that the main relationship with the firm will require significant collection of soft information about the owner. Thus, when the owner is more "important," the firm is more likely to have a main relationship with a small, single-market, or local bank to deal with the soft information under the conventional paradigm. Alternatively, when the owner is more "important," large, multimarket, or nonlocal banks may be more likely to have the main relationship because credit scoring is mostly based on the consumer information on the owner, which may be more important when the owner is more important to the firm.

Turning to main bank characteristics, we use a size cutoff of $\$ 1$ billion in gross total assets (GTA) to distinguish between small and large banks following prior research on the empirical definition of "community banks" (e.g., DeYoung, Hunter, and Udell 2004). Also following prior research and anti-trust guidelines, we define a single-market bank as one in a single metropolitan market - a Metropolitan Statistical Area (MSA) or New England County Metropolitan Areas (NECMA) in which the small business is located. All banks with branch offices in two or more metropolitan or rural markets are defined as multimarket banks. The main bank characteristics include measures of the financial fragility and type of the main bank. In some specifications, we also account for the financial fragility of the main bank by including its equity to gross total assets (GTA) ratio, its ratio of nonperforming loans to total loans, and a measure of its illiquidity (liquidity creation to GTA ratio, taken from Berger and Bouwman 2009).

Banking relationship variables include a dummy for an exclusive bank-firm relationship. We also use a measure of length of the relationship with the main bank. 
Local market characteristics include a control for local market competition in the form of the Herfindahl index of local banking market concentration. In the small bank versus large bank estimation (described more in Section 4 below), we also include a variable to measure the share of local market branches owned by large banks. This is included as a proxy for the relative convenience to large banks. It is expected that firms are more likely to have their main relationship at a large bank if the market presence of this bank type is greater, all else equal. $^{12}$ Similarly, we include multimarket bank share of local market branches in the single-market versus multimarket bank equation to account for the relative convenience of multimarket banks. In the local versus nonlocal bank equation, we include local branches per capita as an indicator of the relative convenience of local banks. We also include an interstate branching index to control for regulatory and competitive conditions (Rice and Strahan 2010).

Summary statistics on these variables are shown in Table 1 Panel B. We briefly discuss some of these here. On average, firms in our sample are about 16 years old, and 67 percent are organized as corporations. The debt to asset ratio of the average firm is 33 percent, and nearly half of the firms have a bank loan. Less than one percent of firms in our sample have declared bankruptcy in the past 7 years, although 17 percent of firms have been delinquent 60 or more days on at least one business obligation in the past three years. These firms are largely family owned and operated: 82 percent of firms are family owned and 89 percent are owner-managed.

Three-quarters of the firms in our sample have large banks as their main banks, and roughly 60 percent have multimarket or nonlocal banks as their main banks. The majority of firms (57 percent) in the sample state that they have only one bank. The high proportion of firms that have large, multimarket or nonlocal banks as their main bank suggests, initially, that the conventional paradigm does not hold - most of our small-firm sample do not have community banks as their main banks.

\section{Empirical Methodology}

\section{Determinants of main bank type}

Our first model examines the effects of firm, owner, and local market characteristics in determining the firm's main bank type:

\footnotetext{
${ }^{12}$ Prior research finds that the local market share of large banks is a powerful predictor of lending bank size (e.g., Berger, Miller, Petersen, Rajan, and Stein 2005, Berger, Rosen, and Udell 2007).
} 
The dependent variables are dummies which equal 1 if the main bank is the given type and 0 otherwise. We distinguish between small and large banks, between single-market and multimarket banks, and between local and nonlocal banks. We estimate binomial logit models specifying the probability of the main bank being large, multimarket, or nonlocal, leaving small, single-market, or local as the excluded base case, respectively.

Our primary tests in equation (1) are based on the discussion above concerning the effects of firm size and age, and the "importance" of principal owner to the firm. We test the hypotheses under the conventional wisdom that "community banks" (small, single-market, and local banks) tend to serve as the main bank for more opaque firms - i.e., smaller, younger firms, with more "important" owners - and "megabanks" (large, multimarket, or nonlocal banks) tend to have their strongest relationship with more transparent firms - i.e., larger, more mature firms, with less "important" owners.

\section{Determinants of relationship strength}

Our second model investigates the determinants of relationship strength. We use logit estimations to study the probability that a firm has an exclusive banking relationship using a dummy for the dependent variable. We also estimate an OLS model using robust standard errors to test for the length of the relationship (where length is defined as the log of (1+ length of firm-bank relationship in months)). We assume that relationship strength is a function of firm, local market, and main bank characteristics as shown in equation (2):

Relationship Strength = g\{Firm and owner characteristics, Local market characteristics, Main bank fragility and type\}

The firm, owner, and local market characteristics in equation (2) are identical to those in equation (1), except that we include all three convenience variables - large bank branch share, multimarket bank branch share, and local market branches per capita together in each version of Equation (2), whereas these entered in different versions of Equation (1). The main bank characteristics include measures of the financial fragility and type of the main bank. As discussed above, for financial fragility, we include the main bank's equity to gross total assets (GTA) ratio, its nonperforming loan ratio, and a measure of its illiquidity.. For main bank type, we simply specify dummies for large bank, multimarket bank, and nonlocal bank, excluding dummies for small, 
single-market, and local banks as the base case.

Using equation (2), we first test the effects of firm size, age, and "importance" of the principal owner on main bank relationship strength. Specifically, we test the hypotheses that smaller, younger firms, with more “important" principal owners are more likely to have exclusive relationships and longer relationships to deal with their soft information problems, while relatively large, more mature firms with less "important" principal owners may more often engage in multiple banking relationships and shorter relationships.

Second, we test the effects of main bank financial fragility on the probability that the firm has multiple banking relationships or short relationships to protect themselves from premature withdrawal of services if their main bank becomes financially distressed or fails. Thus, conditional on the firm and owner characteristics, we expect that multiple relationships and short relationships are more likely when the main bank has a low capital ratio, high nonperforming loan ratio, and high illiquidity. ${ }^{13}$

Third, we test hypotheses regarding the strength of the relationship with the main bank type. Specifically, we test the hypotheses that large, multimarket, and nonlocal banks have weaker ties to the local community, and may be more likely to sever small business relationships or withdraw soft-information-based credit than small, single-market, and local institutions, respectively. Therefore, it is expected that firms that have these bank types are more likely to protect themselves against the fragility of their main banking relationship by engaging in multiple banking or have shorter relationships.

\section{Empirical results}

Tables 2 and 3 show our regression results for the determinants of main bank type (Table 2), and relationship strength (Table 3). We present the estimates as odds ratios (except for the relationship strength regressions which are estimated by OLS) which are obtained by exponentiating the original logit coefficients. For example, in the logit regressions in Table 2 with the probability of a large, multimarket, or nonlocal bank as dependent variable, an odds ratio of one on a firm being medium-sized would indicate that being a medium firm

\footnotetext{
${ }^{13}$ Some studies of multiple banking in other nations use two different models of choice to have multiple banks and number of banks, given multiple banking (e.g., Detragiache, Garella, and Guiso 2000, Berger, Klapper, Martinez Peria, and Zaidi 2008). We argue that such an approach is not appropriate for our sample of U.S. small businesses, which rarely have many more than two relationships.
} 
does not affect the probability of having a "megabank" as its main bank. An odds ratio greater than one on a right-hand-side variable would indicate that a higher value predicts a greater probability of a main bank being a large, multimarket or nonlocal bank, as appropriate. We report the z-statistics, in parentheses, under the odds ratios in all tables.

\section{Determinants of main bank type}

Table 2 reports the results of our first set of tests; that small, single-market, and local banks tend to serve as the main bank for more opaque firms - i.e., smaller, younger firms, with more "important" owners and large, multimarket, and nonlocal banks tend to have their strongest relationship with more transparent firms - i.e., larger, more mature firms, with less "important" owners. Columns 1-3 report these regressions for the main bank being a large bank, multimarket bank, or nonlocal bank, respectively. We find that most of the key exogenous variables have odds ratios that are statistically insignificantly different from one; that is we find little evidence that smaller, younger firms, with more important owners have their strongest relationships with small, single-market and local banks. The one exception is that younger firms are just slightly less likely to have large banks as their main bank - the odds ratio of 1.014 suggests that doubling the age increases the probability of a large main bank by about 1.4 percent. The odds ratio on the large bank share of the market branches is greater than one and statistically significant in the first regression, suggesting that small businesses' choice of large banks is, in part, motivated by the convenience of having a large share of branches of those types of banks in the area. Similarly, the coefficient on multimarket share of branches is significantly greater than one, indicating that convenience of these banks plays a role. In the third regression in column 3 , the odds ratio on the total branches in each market per capita, our proxy of local bank or branch office presence, is less than one, suggesting that small businesses' choice of a local bank is driven partly by the convenience of having a local office in the market.

\section{Determinants of relationship strength}

Table 3 reports the results of our second set of regressions, which tests the effects of firm size, age, and "importance" of the principal owner, as well as the main bank type and financial fragility, on the strength of the main relationship. Column 1 reports the results of equation (2) estimated as a logit model using the exclusive relationship indicator as the endogenous variable, while column 2 reports the results of equation (2), estimated 
as an OLS model with robust standard errors and using the log of one plus the length of the relationship with the main bank as the endogenous variable.

We see in the set of logit regression using the exclusive relationship dummy, that the odds ratios for the medium and large firm indicators are below one and statistically significant, that is, these firms are less likely than small firms to have exclusive relationships with their main banks. This could indicate that small firms have stronger relationships with their main banks, consistent with the predictions of the conventional paradigm, or it could reflect the fact that larger firms demand a larger array of financial services over a greater geographic area, which may require multiple banks. We turn to the regression results for relationship length below to determine which of these explanations is more likely. The odds ratios on whether the main bank is large, multimarket, or nonlocal are insignificantly different from one - inconsistent with the conventional paradigm, which would predict stronger relationships with "community banks." The odds ratio on the equity to asset ratio of the main bank is significantly less than one, suggesting that riskier banks (with lower equity ratios) are more likely to have exclusive relationships, which runs counter to the prediction that firms choose multiple banks to avoid the risk of a fragile main bank.

The OLS regression using the log of one plus the length of the relationship shows that small firms are no more likely than medium or large firms to have a longer relationship with their banks; again inconsistent with the predictions of the conventional paradigm. The estimated coefficients on the age and riskiness of the firms indicate that older and safer firms are more likely to have longer relationships with their banks. The age coefficient may reflect a mechanical association, given that older firms have more years available to have longer relationships, while the risk coefficient may suggest that banks prefer to keep relationships with safer firms. Finally, firms whose main bank is large or multimarket tend to have longer relationship with their banks, contrary to the predictions of the conventional paradigm.

\section{Conclusions}

Bank researchers have traditionally argued that "community banks" - institutions that are small and operate locally in a single market - tend to have the strongest relationships with the smallest, least informationally transparent small businesses. The argument frequently cited is that community bankers are superior at processing "soft" qualitative information about their customers and local communities that is difficult to quantify and transmit over distances and through the communication channels of other banks. "Megabanks" 
- institutions that are large, multimarket, and provide services from outside the local market - in contrast are better at serving larger, more transparent firms using "hard" quantitative information and that may be more easily communicated within these organizations.

Some of the recent literature has challenged the conventional paradigm, finding that large banks do lend to small, opaque firms using hard-information technologies such as small business credit scoring and fixed-asset technologies. However, the literature has not to date spent much effort testing other predictions of the conventional paradigm regarding which type of bank serves as a small business' "main" relationship bank and the strength of the main bank relationship.

In this paper, we test some of these predictions using data from the 2003 SSBF. Specifically, we conduct two sets of tests. First, we test for the type of bank serving as the "main" relationship bank. We find that opaque small businesses are not more likely to have a community bank as their main bank. Second, we test for the strength of these main relationships by examining the probability of multiple relationships and length of the relationship as functions of main bank type and financial fragility, as well as firm and owner characteristics. We find mixed evidence on whether opaque small businesses have stronger relationships with their main banks, but the evidence is clearer that strength does not depend on the type of bank.

There are reasons to believe that this conventional paradigm may have lost hold to some degree over time as technological progress and deregulation has made it easier for megabanks to serve small, opaque firms. To further address this issue, we try to apply our analysis to the $1993 \mathrm{SSBF}$ survey and compare to our main results, since 1993 was before the widespread use of small business credit scoring (the first FICO model for small business credit scoring was made available in 1995) and the passage of IBBEA in 1994 (which allowed large, multimarket and nonlocal banks to integrate offices across state lines). However, the quality of the data prevents us from doing so. In early survey years, a large number of firms were not matched or improperly matched to their main financial institutions. Correct matching of firm to financial institution has been a persistent issue that the survey designers have worked to address more fully with each survey round. In the 1993 survey, only $70 \%$ of firms were matched with their main institution, but by 2003 , this had improved to $88 \%{ }^{14}$ Moreover, the unmatched banks appear to be the smaller banks. Thus, the 1993 survey year leaves us with a small sample size, biased towards large firms.

14 The issue in the early years stems from the survey firm incompletely filling out the name of the institution (for example, "union bank" or "first national bank") when hundreds of such banks had similar names. In later years, the survey design was improved to eliminate errors of this sort. 


\section{$\underline{\text { References }}$}

Avery, R.B., and Samolyk, K.A., 2004. Bank consolidation and the provision of banking services: Small commercial loans, Journal of Financial Services Research 25, 291-325.

Berger, A.N., and Black, L.K., 2011. Bank Size, Lending Technologies, and Small Business Finance, Journal of Banking and Finance 35, 724-735.

Berger, A.N., Bonime, S.D., Goldberg, L.G., and White, L.J., 2004. The dynamics of market entry: The effects of mergers and acquisitions on entry in the banking industry, Journal of Business 77, 797-834.

Berger, A.N., Bouwman C.H.S., 2009. Bank liquidity creation, Review of Financial Studies 22, 3779-3837.

Berger, A.N., Cerqueiro, G., and Penas, M.F., 2013. Market size structure and small business lending: Are crisis times different from normal times?, University of South Carolina working paper.

Berger, A.N., Cowan, A.M., and Frame, W.S., 2011. The surprising use of credit scoring in small business lending by community banks and the attendant Effects on credit availability, risk, and profitability, Journal of Financial Services Research 39, 1-17.

Berger, A.N., Frame, W.S., and Miller, N., 2005. Credit Scoring and the Availability, Price, and Risk of Small Business Credit, Journal of Money, Credit, and Banking 37, 191-222.

Berger, A.N., Hasan, I., and Klapper, L.F., 2004. Further evidence on the link between finance and growth: An international analysis of community banking and economic performance, Journal of Financial Services Research 25, 169-202.

Berger, A.N., Klapper L.F., and Udell, G.F., 2001. The ability of banks to lend to informationally opaque small businesses, Journal of Banking and Finance 25, 2127-2167.

Berger, A.N., Klapper L.F., Martinez Peria, M.S., and Zaidi, R. 2008. Bank Ownership Type and Banking Relationships, Journal of Financial Intermediation 17, 37-62.

Berger, A.N., Miller, N.H., Petersen, M.A., Rajan, R.G., and Stein, J.C., 2005. Does function follow organizational form? Evidence from the lending practices of large and small banks, Journal of Financial Economics 76, 237-269.

Berger, A.N., and Ostromogolsky, P, 2009. The Effects of Banks on 'Debt-Sensitive' Small Businesses, Journal of Financial Economic Policy 1, 44-79.

Berger, A.N., Rosen, R.J., and Udell, G.F., 2007. Does market size structure affect competition? The case of small business lending, Journal of Banking and Finance 31, 11-33.

Berger, A.N., Saunders, A., Scalise, J.M., and Udell, G.F., 1998. The effects of bank mergers and acquisitions on small business lending, Journal of Financial Economics 50, 187-229.

Berger, A.N., and Udell, G.F., 1995. Relationship lending and lines of credit in small firm finance, Journal of Business 68, 351-381.

Berger, A.N., and Udell, G.F., 2002. Small business credit availability and relationship lending: The importance of bank organizational structure, Economic Journal 112, 32-53.

Berger, A.N., and Udell, G.F., 2006. A More Complete Conceptual Framework for SME Finance, Journal of 
Banking and Finance 30, 2945-2966.

Bharath, S., Dahiya, S., Saunders,.A., and Srinivasan, A., 2007. So What Do I Get? The Bank's View of Lending, Journal of Financial Economics 85, 368-419.

Black S.E., and Strahan, P.E., 2002. Entrepreneurship and bank credit availability, Journal of Finance 57, 28072833.

Bonaccorsi di Patti, E., and Dell'Ariccia, G., 2004. Bank competition and firm creation, Journal of Money, Credit, and Banking 36, 225-251.

Boot, A.W.A., 2000. Relationship banking: What do we know?, Journal of Financial Intermediation 9, 7-25.

Brevoort, K.P., and Hannan, T.H., 2006. Commercial Lending and Distance: Evidence from Community Reinvestment Act Data, Journal of Money, Credit, and Banking 38, 1991-2012.

Cetorelli, N., 2004. Bank concentration and competition in Europe, Journal of Money, Credit, and Banking 36, 543-558.

Cetorelli, N., and Gambera, M., 2001. Banking market structure, financial dependence and growth: International evidence from industry data, Journal of Finance 56, 617-648.

Cetorelli, N., and Strahan, P.E., 2006. Finance as a barrier to entry: Bank competition and industry structure in local U.S. markets, Journal of Finance 61.

Canales, R., and Nanda, R., 2012. A Darker Side to Decentralized Banks: Market Power and Credit Rationing in SME Lending, Journal of Financial Economics 105, 353-366.

Claessens, S., and Van Horen, N., 2011. Trends in foreign banking: A database on bilateral foreign bank ownership, Dutch Central Bank Working Paper

Cohen, A., and Mazzeo, M. J., 2007. Market Structure and Competition among Retail Depository Institutions, Review of Economics and Statistics 89.

Cole, R., 1998. The importance of relationships to the availability of credit, Journal of Banking and Finance 22, 959-977.

Cole, R. A., Goldberg, L.G., and White, L.J., 2004. Cookie-cutter versus character: The micro structure of small business lending by large and small banks, Journal of Financial and Quantitative Analysis 39, 227-251.

Dahiya, S., Kose, J., Manju, P., and Gabriel, R., 2003. Debtor-in-possession financing and bankruptcy resolution: Empirical evidence, Journal of Financial Economics 69, 259-280.

de la Torre, A., Martinez Peria, M.S., and Schmukler, S.L. 2010. Bank involvement with SMEs: Beyond relationship lending, Journal of Banking and Finance, forthcoming.

Degryse, H., and Van Cayseele, P., 2000. Relationship lending within a bank-based system: Evidence from European small business data, Journal of Financial Intermediation 9, 90-109.

Detragiache, E., Garella, P., and Guiso, L., 2000. Multiple versus single banking relationships: Theory and evidence, Journal of Finance 55, 1133-1161. 
de Haas, R., and Van Lelyveld, I., 2011. Multinational banks and the global financial crisis: Weathering the perfect storm, Dutch National Bank Working paper No. 322.

DeYoung, R., Frame, W.S., Glennon, D., and Nigro, P., 2011. The information revolution and small business lending: The missing evidence, Journal of Financial Services Research 39, 19-33.

DeYoung, R., Hunter, W.C., and Udell, G.F., 2004. The Past, Present, and Probable Future for Community Banks, Journal of Financial Services Research 25, 85-133.

DeYoung, R., Glennon, D., Nigro, P., and Spong, K., 2012. Small Business Lending and Social Capital: Are Rural Relationships Different?, University of Kansas Center for Banking Excellence Research paper \# 2012-1.

Durguner, S., 2012. Effects of changes in borrower-lender relationships on small business loan contract terms and credit availability, University of Illinois at Urbana-Champaign Working paper.

Elsas, R., 2005. Empirical determinants of relationship lending, Journal of Financial Intermediation 14, 32-57.

Elsas, R., Heinemann, F., and Tyrell, M., 2004. Multiple but Asymmetric Bank Financing: The Case of Relationship Lending, CESifo Working Paper Series No. 1251.

Elsas, R., and Krahnen, J.P., 1998. Is relationship lending special? Evidence from credit-file data in Germany, Journal of Banking and Finance 22, 1283-1316.

Farinha, L.A., and Santos, J.A.C., 2002. Switching from single to multiple bank lending relationships: Determinants and implications, Journal of Financial Intermediation 11, 124-151.

Frame, W.S., Padhi, M., and Woolsey L., 2004. The Effect of Credit Scoring on Small Business Lending in Low- and Moderate Income Areas, Financial Review 39, 35-54.

Frame, W.S., Srinivasan, A., and Woosley, L., 2001. The Effect of Credit Scoring on Small Business Lending, Journal of Money, Credit, and Banking 33, 813-825.

Gilje, E., 2012. Does Local Access To Finance Matter?: Evidence from U.S. Oil and Natural Gas Shale Boom, Boston College working paper.

Hannan, T. H., 2003. Changes in Non-Local Lending to Small Business, Journal of Financial Services Research 24, 31-46.

Hannan, T. H., and Prager, R.A., 2006. The profitability of small, single-market banks in an era of multimarket banking, Finance and Economics Discussion Series (FEDS) 2006-41.

Harhoff, D., and Korting, T., 1998. Lending relationships in Germany - Empirical evidence from survey data, Journal of Banking and Finance 22, 1317-1353.

Haynes, G.W., Ou, C., and Berney, R., 1999. Small business borrowing from large and small banks, In: Blanton, J.L., Williams, A., Rhine, S.L.W. (Eds.), Business Access to Capital and Credit. Federal Reserve System Research Conference, pp. 287-327.

Herrera, A.M., and Minetti, R., 2007. Informed finance and technological change: Evidence from credit relationships, Journal of Financial Economics 83, 223-269.

Houston, J.F., and James, C.M., 1996. Bank information monopolies and the mix of private and public debt 
choices, Journal of Finance 51, 1863-1889.

Jayaratne, J., and Wolken. J., 1999. How important are small banks to small business lending? New evidence from a survey of small firms, Journal of Banking and Finance 23, 427-458.

Karceski, J., Ongena, S., and Smith, D., 2005. The impact of bank consolidation on commercial borrower welfare, Journal of Finance 60: 2043-2082.

Klein, M., Peek, J., and Rosengren, E., 2002. Troubled banks, impaired foreign direct investment: The role of relative access to credit, American Economic Review 92, 664-682.

Machauer, A., and Weber, M., 2000. Number of bank relationships: an indicator of competition, borrower quality or just size?, Johan Wolfgang Goethe-Universitat Center for Financial Studies Working Paper No. 2000/06.

Ongena, S., Peydró, J., and van Horen, N., 2012. Shocks abroad, pain at home? Bank-firm level evidence on financial contagion during the recent financial crisis, Tilburg University Working paper.

Ongena, S., and Smith, D., 2000. What determines the number of bank relationships? Cross-country evidence, Journal of Financial Intermediation 9, 26-56.

Petersen, M.A., and Rajan, R.G., 1994. The benefits of lending relationships: Evidence from small business data, Journal of Finance 49, 3-37.

Petersen, M.A., and Rajan, R.G., 1995. The effect of credit market competition on lending relationships, Quarterly Journal of Economics 110, 407-443.

Petersen, M.A., and Rajan, R.G., 2002. The Information Revolution and Small Business Lending: Does Distance Still Matter?, Journal of Finance 57, 2533-2570.

Popov, A., and Udell, G.F., 2012. Cross-border banking, credit access, and the financial crisis, Journal of International Economics 87, 147-161.

Rajan, R.G., 1992. Insiders and outsiders: The choice between informed and Arm's-length debt, Journal of Finance 47, 1367-1400.

Rice, T. and Strahan, P.E., 2010. Does credit competition affect small-firm finance?, Journal of Finance 65, 861889.

Robb, A., and Robinson, D., The capital structure decisions of new firms, Review of Financial Studies, forthcoming.

Rosenfeld, C. M., 2011. The Effect of Banking Relationships on the Future of Financially Distressed Firms, College of William and Mary working paper.

Scott, J.A., 2004. Small business and value of community financial institutions, Journal of Financial Services Research 25, 207-230.

Sharpe, S.A., 1990. Asymmetric information, bank lending, and implicit contracts: A stylized model of customer relationships, Journal of Finance 45, 1069-87.

Stein, J.C., 2002. Information production and capital allocation: Decentralized vs. hierarchical firms, Journal of Finance 57, 1891-1921. 
U.S. Small Business Administration, Office of Advocacy, 2010. Frequently Asked Questions about Small Business Finance. Washington: Small Business Administration.

Van Ewijk, S., and Arnold, I., 2013. How bank business models drive interest margins: Evidence from US banklevel data, Nyenrode Business Universiteit working paper.

Von Thadden, E., 1992. The commitment of finance, duplicated monitoring, and the investment horizon, CEPR Working Paper No. 27.

Williamson, O., 1988. Corporate finance and corporate governance, Journal of Finance 43, 567-91. 
Table 1

Panel A: Variable descriptions

This panel reports variable names and descriptions of data from the 2003 Survey of Small Business Finance (SSBF) combined with the 2003:Q4 Bank Call Reports and June 2003 Summary of Deposits.
Variable
Description

Firm characteristics

Indicator if small firm

Equals one if firm has assets less than or equal to $\$ 100,000$, zero otherwise

Indicator if medium firm

Equals one if firm has assets greater than $\$ 100,000$ and less than or equal to

Indicator if large firm

$\$ 1$ million, zero otherwise.

Percent minority owned

Equals one if firm has assets greater than \$1 million, zero otherwise

Indicator if firm is delinquent on payments

Percentage of firm ownership that is non-white.

Firm risk rating (6 is safest; 1 is riskiest)

Equals one if firm has been 60 or more days delinquent on business obligations at least once within the past three years, zero otherwise

Leverage ratio of firm

Firm's credit score as obtained from Dun and Bradstreet.

Indicator if firm has a bank loan

Firm age

Ratio of firm debt to equity.

Equals one if firm has any type of bank loan, zero otherwise

How many years ago was the firm established/purchased/acquired by the current owners.

Indicator if firm has declared bankruptcy

Equals one if the firm has declared bankruptcy within the last seven years, zero otherwise.

Owner characteristics

Indicator if owner is manager

Equals one if owner is responsible for day-to-day management of the business, zero otherwise.

Indicator if family owned

Equals one if the firm was owned exclusively by members of the same family, zero otherwise.

Indicator if proprietorship

Indicator if partnership

Equals one if the firm is a sole proprietorship, zero otherwise

Indicator if corporation

Equals one if the firm is a partnership, zero otherwise

Main bank characteristics Equals one if the firm is a $\mathrm{S}$ or $\mathrm{C}$ corporation, zero otherwise

Indicator if main bank is large

Equal one if the main bank has assets greater than $\$ 1$ billion, zero otherwise.

Indicator if main bank is multimarket

Equals one if the main bank has branches in multiple (metropolitan or rural) markets, zero otherwise.

Indicator if main bank is nonlocal

Equals one if the main bank does not have a branch in the firm's local market, zero otherwise.

Equity to asset ratio of main bank

Ratio of equity to total assets of main bank.

NPL ratio of main bank

Ratio of non-performing loans to total loans of main bank

Illiquidity of main bank

Berger and Bouwman's (2009) preferred liquidity creation measure divided by gross total assets of the main bank.

Main banking relationship characteristics

Indicator if firm has exclusive relationship with main bank

Length of relationship with main bank (months)

Equals one if firm has a relationship with only main bank, zero otherwise Market controls Shown here in levels but used in logs in regressions

Large bank share of branches (percent)

Percentage of branches with gross total assets greater than $\$ 1$ billion in the market, where the market is the Metropolitan Statistical Area (MSA) or New England County Metropolitan Areas (NECMA).

Multimarket bank share of branches (percent) Percentage of branches in banks with branches in multiple (metropolitan and rural) markets.

Local branches per capita

Branches per 1000 capita in the local market.

Market concentration (HHI)

Sum of the squared shares of deposits held by all banks in the firm’s local market.

Branching restriction index

Rice and Strahan's (2010) time-varying index capturing state-level differences in regulatory constraints between 1994 and 2005, which takes the values between 0 and 4, with 0 being the least restrictive (most open). 
Table 1

Panel B: Summary statistics

This panel reports summary statistics from the 2003 Survey of Small Business Finance (SSBF) combined with the 2003:Q4 Bank Call Reports and June 2003 Summary of Deposits. We have financial data for about $92 \%$ of main banks associated with observations from the SSBF, although there are some cases where the main bank could not be merged with the other sources.

Variable

Firm characteristics

Indicator if small firm

Indicator if large firm

Indicator if medium firm

Percent minority owned

Indicator if firm is delinquent on payments

Firm risk rating (6 is safest; 1 is riskiest)

Leverage ratio of firm

Indicator if firm has a bank loan

Firm age

Indicator if firm has declared bankruptcy

Owner characteristics

Indicator if owner is manager

Indicator if family owned

Indicator if proprietorship

Indicator if partnership

Indicator if corporation

Main bank characteristics

Indicator if main bank is large

Indicator if main bank is multimarket

Indicator if main bank is nonlocal

Equity to asset ratio of main bank

NPL ratio of main bank

Illiquidity of main bank

Main banking relationship characteristics

Indicator if firm has exclusive relationship with main bank

Length of relationship with main bank (months)

Market controls

Large bank share of branches (percent)

Multimarket share of branches (percent)

Local branches per capita

Market concentration (HHI)

Branching restriction index

\begin{tabular}{|c|c|c|}
\hline Obs. & Mean & Std. Dev. \\
\hline 2846 & 0.408 & 0.491 \\
\hline 2846 & 0.312 & 0.463 \\
\hline 2846 & 0.280 & 0.449 \\
\hline 2846 & 0.138 & 0.345 \\
\hline 2846 & 0.165 & 0.372 \\
\hline 2846 & 3.865 & 1.454 \\
\hline 2846 & 0.327 & 0.390 \\
\hline 2846 & 0.491 & 0.500 \\
\hline 2846 & 16.359 & 12.186 \\
\hline 2846 & 0.008 & 0.090 \\
\hline 2846 & 0.889 & 0.314 \\
\hline 2846 & 0.824 & 0.381 \\
\hline 2846 & 0.284 & 0.451 \\
\hline 2846 & 0.050 & 0.218 \\
\hline 2846 & 0.666 & 0.472 \\
\hline 2846 & 0.747 & 0.435 \\
\hline 2614 & 0.633 & 0.482 \\
\hline 2846 & 0.593 & 0.491 \\
\hline 2614 & 0.090 & 0.030 \\
\hline 2614 & 0.013 & 0.010 \\
\hline 2614 & 0.440 & 0.148 \\
\hline 2846 & 0.572 & 0.495 \\
\hline 2846 & 12.143 & 10.104 \\
\hline 2846 & 79.299 & 14.766 \\
\hline 2846 & 49.232 & 23.573 \\
\hline 2846 & 0.097 & 0.183 \\
\hline 2846 & 0.136 & 0.060 \\
\hline 2846 & 2.098 & 1.291 \\
\hline
\end{tabular}


Table 2

Determinants of main bank type

Regressions are weighted by survey weights to account for disproportionate sampling and nonresponse, and include a set of twodigit SIC indicator variables to control for industry effects (not shown). Our full dataset consists of 2846 observations; after merging with the Summary of Deposits this is reduced to 2614. Within this subset, one of the SIC dummies perfectly predicts a multimarket bank as the main bank, which leads to omission of this indicator and four associated observations. We present estimates as odds ratios, which are obtained by exponentiating the original logit coefficients. An odds ratio of one would indicate that the regressor has no effect on the probability that the dependent variable takes a value of one. An odds ratio greater/less than one indicates that an increase in the regressor increases/decreases the probability that the dependent variable takes a value of one.

\begin{tabular}{|c|c|c|c|}
\hline & $\begin{array}{c}\text { (1) } \\
\text { Main bank is } \\
\text { large bank }\end{array}$ & $\begin{array}{c}\text { (2) } \\
\text { Main bank is } \\
\text { multimarket } \\
\text { bank }\end{array}$ & $\begin{array}{c}\text { (3) } \\
\text { Main bank is } \\
\text { nonlocal bank }\end{array}$ \\
\hline \multicolumn{4}{|l|}{ Firm characteristics } \\
\hline Indicator if medium firm & $\begin{array}{c}1.158 \\
(1.048)\end{array}$ & $\begin{array}{c}1.051 \\
(0.390)\end{array}$ & $\begin{array}{c}1.076 \\
(0.617)\end{array}$ \\
\hline Indicator if large firm & $\begin{array}{c}1.041 \\
(0.202)\end{array}$ & $\begin{array}{c}0.852 \\
(-0.861)\end{array}$ & $\begin{array}{c}0.989 \\
(-0.065)\end{array}$ \\
\hline Percent minority owned & $\begin{array}{c}1.868^{* * *} \\
(3.259)\end{array}$ & $\begin{array}{c}1.612 * * * \\
(2.925)\end{array}$ & $\begin{array}{l}1.301^{*} \\
(1.810)\end{array}$ \\
\hline Indicator if firm is delinquent on payments & $\begin{array}{c}0.915 \\
(-0.542)\end{array}$ & $\begin{array}{c}1.010 \\
(0.063)\end{array}$ & $\begin{array}{c}1.152 \\
(0.969)\end{array}$ \\
\hline Firm risk rating (6 is safest; 1 is riskiest) & $\begin{array}{c}1.022 \\
(0.485)\end{array}$ & $\begin{array}{c}1.052 \\
(1.251)\end{array}$ & $\begin{array}{c}1.040 \\
(1.019)\end{array}$ \\
\hline Leverage ratio of firm & $\begin{array}{c}0.803 \\
(-1.378)\end{array}$ & $\begin{array}{c}0.850 \\
(-1.146)\end{array}$ & $\begin{array}{c}1.162 \\
(1.145)\end{array}$ \\
\hline Firm age (log years) & $\begin{array}{l}1.014^{* *} \\
(2.300)\end{array}$ & $\begin{array}{c}1.001 \\
(0.219)\end{array}$ & $\begin{array}{c}1.003 \\
(0.553)\end{array}$ \\
\hline Indicator if firm declared bankruptcy & $\begin{array}{c}0.676 \\
(-0.793)\end{array}$ & $\begin{array}{c}0.682 \\
(-0.721)\end{array}$ & $\begin{array}{c}0.398^{*} \\
(-1.688)\end{array}$ \\
\hline \multicolumn{4}{|l|}{ Owner characteristics } \\
\hline Indicator if owner is manager & $\begin{array}{l}1.052 \\
(0.199)\end{array}$ & $\begin{array}{c}1.356 \\
(1.251)\end{array}$ & $\begin{array}{c}0.720 \\
(-1.464)\end{array}$ \\
\hline Indicator if family owned & $\begin{array}{c}0.928 \\
(-0.374)\end{array}$ & $\begin{array}{c}0.978 \\
(-0.128)\end{array}$ & $\begin{array}{l}1.064 \\
(0.388)\end{array}$ \\
\hline Indicator if partnership & $\begin{array}{l}1.208 \\
(0.635)\end{array}$ & $\begin{array}{c}2.021^{* *} \\
(2.461)\end{array}$ & $\begin{array}{c}0.935 \\
(-0.270)\end{array}$ \\
\hline Indicator if corporation & $\begin{array}{c}1.166 \\
(1.051)\end{array}$ & $\begin{array}{c}1.083 \\
(0.596)\end{array}$ & $\begin{array}{c}0.797^{*} \\
(-1.853)\end{array}$ \\
\hline \multicolumn{4}{|l|}{ Market controls } \\
\hline Large bank share of branches & $\begin{array}{l}1.060 * * * \\
(12.784)\end{array}$ & & \\
\hline Multimarket share of branches & & $\begin{array}{c}3.685^{* * * *} \\
(5.306)\end{array}$ & \\
\hline Local branches per capita & & & $\begin{array}{l}0.276 * * \\
(-2.351)\end{array}$ \\
\hline Market concentration (HHI) & $\begin{array}{c}4.378 \\
(1.311)\end{array}$ & $\begin{array}{c}1.482 \\
(0.411)\end{array}$ & $\begin{array}{c}0.059 * * * \\
(-3.049)\end{array}$ \\
\hline Branching restriction index & $\begin{array}{c}0.987 \\
(-0.284)\end{array}$ & $\begin{array}{c}0.941 \\
(-1.355)\end{array}$ & $\begin{array}{c}1.022 \\
(-0.548)\end{array}$ \\
\hline Constant & $\begin{array}{c}0.019 * * * \\
(-7.086)\end{array}$ & $\begin{array}{c}0.624 \\
(-1.178)\end{array}$ & $\begin{array}{c}3.030 * * * \\
(3.059)\end{array}$ \\
\hline $\mathrm{N}$ & 2846 & 2610 & 2846 \\
\hline
\end{tabular}

Robust z-statistics of the hypothesis that the odds ratios equal one are given in parentheses. ${ }^{* * *} \mathrm{p}<0.01,{ }^{* *} \mathrm{p}<0.05, * \mathrm{p}<0.1$ 
Table 3

Determinants of main banking relationship strength

Regressions are weighted by survey weights to account for disproportionate sampling and nonresponse, and include a set of two-digit SIC indicator variables to control for industry effects. Our full dataset consists of 2846 observations; after merging with the Summary of Deposits this is reduced to 2614. We present estimates of the logit specification in column (1) as odds ratios, which are obtained by exponentiating the original logit coefficients. An odds ratio of one would indicate that the regressor has no effect on the probability that the dependent variable takes a value of one. An odds ratio greater/less than one indicates that an increase in the regressor increases/decreases the probability that the dependent variable takes a value of one. We present estimates of the OLS specification in column 2 as coefficients.

\begin{tabular}{|c|c|c|}
\hline & $\begin{array}{c}(1) \\
\text { Firm has } \\
\text { exclusive } \\
\text { relationship }\end{array}$ & $\begin{array}{c}\text { (2) } \\
\text { Length of } \\
\text { relationship }\end{array}$ \\
\hline \multicolumn{3}{|l|}{ Firm characteristics } \\
\hline Indicator if medium firm & $\begin{array}{c}0.478^{* * *} \\
(-5.811)\end{array}$ & $\begin{array}{c}0.027 \\
(-0.651)\end{array}$ \\
\hline Indicator if large firm & $\begin{array}{c}0.346^{* * *} \\
(-5.968)\end{array}$ & $\begin{array}{c}0.033 \\
(-0.545)\end{array}$ \\
\hline Percent minority owned & $\begin{array}{c}0.775 \\
(-1.609)\end{array}$ & $\begin{array}{c}-0.022 \\
(-0.507)\end{array}$ \\
\hline Indicator if firm is delinquent on payments & $\begin{array}{c}0.816 \\
(-1.271)\end{array}$ & $\begin{array}{c}0.033 \\
(-0.608)\end{array}$ \\
\hline Firm risk rating ( 6 is safest; 1 is riskiest) & $\begin{array}{c}0.975 \\
(-0.617)\end{array}$ & $\begin{array}{l}0.049 * * * \\
(-3.348)\end{array}$ \\
\hline Leverage ratio of firm & $\begin{array}{c}0.357^{\text {*** }} \\
(-7.228)\end{array}$ & $\begin{array}{c}-0.056 \\
(-1.196)\end{array}$ \\
\hline Firm age (log years) & $\begin{array}{c}0.998 \\
(-0.377)\end{array}$ & $\begin{array}{c}0.033^{* * *} \\
(-14.75)\end{array}$ \\
\hline Indicator if firm declared bankruptcy & $\begin{array}{c}1.268 \\
(-0.447)\end{array}$ & $\begin{array}{c}0.256 \\
(-1.384)\end{array}$ \\
\hline \multicolumn{3}{|l|}{ Owner characteristics } \\
\hline Indicator if owner is manager & $\begin{array}{c}0.833 \\
(-0.858)\end{array}$ & $\begin{array}{c}0.098 \\
(-1.437)\end{array}$ \\
\hline Indicator if family owned & $\begin{array}{c}0.771 \\
(-1.497)\end{array}$ & $\begin{array}{c}0.093^{*} \\
(-1.755)\end{array}$ \\
\hline Indicator if partnership & $\begin{array}{l}1.709 * \\
(-1.72)\end{array}$ & $\begin{array}{c}-0.066 \\
(-0.672)\end{array}$ \\
\hline Indicator if corporation & $\begin{array}{l}1.307^{* *} \\
(-2.062)\end{array}$ & $\begin{array}{c}-0.062 \\
(-1.467)\end{array}$ \\
\hline \multicolumn{3}{|l|}{ Main bank characteristics } \\
\hline Indicator if main bank is large & $\begin{array}{c}1.15 \\
(-0.814)\end{array}$ & $\begin{array}{c}0.152^{* * *} \\
(-2.766)\end{array}$ \\
\hline Indicator if main bank is multimarket & $\begin{array}{c}1.148 \\
(-1.062)\end{array}$ & $\begin{array}{c}0.132^{* * *} \\
(-3.036)\end{array}$ \\
\hline Indicator if main bank is nonlocal & $\begin{array}{c}0.986 \\
(-0.100)\end{array}$ & $\begin{array}{c}-0.058 \\
(-1.296)\end{array}$ \\
\hline Equity to asset ratio of main bank & $\begin{array}{l}0.005^{* *} \\
(-2.532)\end{array}$ & $\begin{array}{c}-0.104 \\
(-0.180)\end{array}$ \\
\hline NPL ratio of main bank & $\begin{array}{c}0.107 \\
(-0.425)\end{array}$ & $\begin{array}{c}-3.096 \\
(-1.037)\end{array}$ \\
\hline Illiquidity of main bank & $\begin{array}{c}0.561 \\
(-1.584)\end{array}$ & $\begin{array}{c}-0.021 \\
(-0.168)\end{array}$ \\
\hline \multicolumn{3}{|l|}{ Market controls } \\
\hline Large bank share of branches & $\begin{array}{c}1.006 \\
(-1.415)\end{array}$ & $\begin{array}{c}-0.003^{* *} \\
(-2.025)\end{array}$ \\
\hline Multimarket share of branches & $\begin{array}{c}0.82 \\
(-0.776)\end{array}$ & $\begin{array}{c}-0.122 \\
(-1.369)\end{array}$ \\
\hline Local branches per capita & $\begin{array}{c}0.593 \\
(-1.307)\end{array}$ & $\begin{array}{c}-0.07 \\
(-0.556)\end{array}$ \\
\hline Market concentration (HHI) & $\begin{array}{c}0.724 \\
(-0.302)\end{array}$ & $\begin{array}{c}0.101 \\
(-0.327)\end{array}$ \\
\hline Branching restriction index & $\begin{array}{c}1.170^{* * *} \\
(-3.49)\end{array}$ & $\begin{array}{c}0.007 \\
(-0.506)\end{array}$ \\
\hline Constant & $\begin{array}{c}5.334 * * * \\
(-3.054)\end{array}$ & $\begin{array}{c}1.465^{* * *} \\
(-7.798)\end{array}$ \\
\hline $\mathrm{N}$ & 2,614 & 2,614 \\
\hline
\end{tabular}

Robust z-statistics of the hypothesis that odds ratios equal one (col. 1) or coefficients equal zero (col. 2) are given in parentheses.

*** $\mathrm{p}<0.01, * * \mathrm{p}<0.05, * \mathrm{p}<0.1$ 